\title{
On the Reform of Business English Teaching in Higher Vocational Colleges from the Perspective of Instrumentality
}

\author{
Meilian Jiao* \\ Yunnan College of Foreign Affairs \& Foreign Language, Kunming, Yunnan, China \\ *Corresponding author. Email: 13669769597@163.com
}

\begin{abstract}
With the initiative of "one belt and one road", the demand for business English professionals continues to increase, and business English subjects in vocational colleges are facing good opportunities for development. However, the current graduates of business English major in higher vocational colleges are difficult to meet the market demand. Based on the characteristics of English education and vocational education, this paper analyzes the current situation of business English Teaching in higher vocational colleges, and explores the teaching reform of business English in Higher Vocational Colleges from the perspective of the tool attribute of business English, in order to provide a new thinking angle and practical path for the reform of Business English Teaching in domestic higher vocational colleges. All manuscripts must be in English, also the table and figure texts, otherwise we cannot publish your paper.
\end{abstract}

Keywords: Higher vocational colleges, business English, instrumentality, teaching reform

\section{INTRODUCTION}

Since the Ministry of Education approved the first business English undergraduate site in 2007, business English as an independent discipline has developed for more than ten years in China. Under the trend of globalization, international economic and trade activities are becoming more and more frequent. Therefore, the demand for business English professionals is growing rapidly. Colleges and universities that offer business English majors are also growing rapidly. Up to now, there are more than 200 undergraduate colleges and universities offering business English major in China. The increase speed of business English major in junior college and higher vocational education colleges is also accelerating unprecedentedly. The proposal of the "one belt and one way" initiative in 2013 has further increased the demand for business English talents with strong practical ability in the domestic society and along the belt and road, and the development of business English Majors in vocational colleges is facing a new round of good momentum.

\section{CHARACTERISTICS OF BUSINESS ENGLISH}

Business English major "mainly trains senior English professionals with solid English language foundation, systematic theoretical knowledge of international business management, strong practical skills and ability to engage in translation, management, teaching and research in foreign trade, foreign affairs, culture, press and publication, education, scientific research, tourism and other departments." It can be seen that the talents to be trained in Business English are first defined as "English talents", that is, the core of business English teaching finally fall on "English", with special emphasis on "strong practical skills". Combined with the guiding ideology of "insist on English application-oriented" in College English Teaching in 2017 College English teaching guide, it is not difficult to see that business English has all the characteristics of "English", especially its "instrumentality".

Instrumentality is a discipline characteristic relative to humanity. In short, instrumentality emphasizes that the purpose of a certain subject is to teach students to master and skillfully use a method or means to achieve a certain purpose; while humanity emphasizes the most fundamental purpose of the subject is to "educate people", so that students can comprehensively improve their healthy personality and spiritual state. With the popularization of English education in our country, the topic of "instrumentality" and "humanity" has been in the stage of in-depth discussion in the research process of English education and College English education in the domestic academic circles. However, as a new independent subject, business English is rarely studied as a tool. 


\section{THE MAIN CHARACTERISTICS OF HIGHER VOCATIONAL EDUCATION}

Higher vocational education is an important part of higher education in China. At the beginning of the establishment of higher vocational education, it is to cultivate the technical talents who can serve as practical operation or technical guidance in the front-line posts, and solve the structural imbalance between the output of talents and the market demand of social human resources. The main feature of higher vocational education different from general higher education is that its talent training target is "technical talents with higher cultural knowledge and political literacy". For this reason, the main feature of its talent training process, which is different from that of general higher education, is to pay attention to practical teaching and practical training

\section{THE CURRENT SITUATION AND PROBLEMS OF BUSINESS ENGLISH TEACHING IN HIGHER VOCATIONAL COLLEGES}

According to the "professional teaching standards of Higher Vocational Schools (Trial)" compiled by the Department of vocational education and adult education of the Ministry of education in 2012, business English major of higher vocational colleges aims to cultivate students who can meet the needs of the first line of international business, develop in an all-round way morally, intellectually, physically, aesthetically and laboriously, have good ideological and moral quality, professional quality, cultural quality and psychological quality, and have strong English application ability, familiar with the basic theoretical knowledge and business process in the field of international business industry, able to complete the front-line tasks such as international marketing, foreign trade document production, customer service, and high-end skilled English talents with professional sustainable development ability ". From this description, it can be seen that business English in higher vocational education is essentially a specialized English subject, and its most important purpose is to make the training objectives be able to use English as a means and carrier of communication and expression in real international trade-related occasions, so as to achieve its expected purpose. Obviously, business English is emphasized as a "tool", which inherits the "tool" of general English education. However, in terms of the current situation of business English professional training in higher vocational colleges, students have little awareness of the tool attribute of business English. Business English teaching generally fails to meet the expected standards, and students' English proficiency is generally low. Even among the students with relatively good foundation, "dumb English" is very common. There are many students who can't answer the right questions in writing, just because they can't read them. The reasons can be summarized as follows.

\subsection{Teachers Do Not Have a Strong Understanding of Business English, and They Do Not Pay Enough Attention to Its Instrumentality and Practicality}

In the CNKI general database, input "business English, instrumental" for retrieval, and the result is zero, which shows that the research on the relationship between business English and instrumentality is still in a blank stage. This shows that the relevant teaching and research personnel of business English major have not paid attention to the tool attribute of business English, or at least have not paid attention to the importance of tool attribute for the discipline construction and teaching of business English major. Therefore, in the process of business English teaching, the highlight of "practical skills" comes from two aspects: first, it inherits the requirements of general English teaching on five skills of listening, speaking, reading, writing and translation; second, it focuses on the requirements of higher vocational education for practical training. However, neither of them is enough to make teachers realize the inherent nature of business English, and of course, it cannot attract enough attention.

\subsection{The Teaching and Evaluation Methods Are Conservative and Lack of Innovation}

English education has a long history of popularization in China. Both students and teachers have been used to the teaching method of giving lectures as the main way, breaking down and analyzing the language from the aspects of pronunciation, vocabulary, grammar, writing, translation and mechanically repeating the training for memory. Therefore, in Higher Vocational Business English teaching, from school to teachers, to a large extent, they copy the evaluation and measurement standards of general English teaching, requiring students to pass the English A, B or business English level examination, and take it as a hard index to measure the teaching effect. Therefore, the teaching process is naturally guided by this, teachers and students focus on improving the passing rate of examination, so the atmosphere of examination oriented education has been flourishing for a long time. Under such a teaching mode, students lack a basic understanding of the instrumental attributes of English, not to mention conscious training. 


\subsection{The Language Environment Is Generally Lacking, and the Training Sites and Projects Are Not Sufficient}

According to the teaching standards of business English major in higher vocational colleges, the school training base of business English major should at least include language training room, business simulation room and comprehensive training room. In addition to the basic conditions for language skills training, these training rooms also need to provide students with simulated office scenes, real office equipment training, foreign reception, business communication negotiation and other simulated training, so as to create as real a language environment as possible for students, to achieve the effect of language use training in special occasions. At the same time, it also requires a sufficient scale of off campus training base in order to achieve the standard of talent training. However, the general situation of higher vocational colleges is that the basic language training room is relatively complete, but the number may not be able to meet the needs of students. As for the construction of business simulation room and comprehensive training room, many schools are completely absent. A small number of Vocational Colleges with complete business training rooms are facing the awkward situation that teachers are unable to conduct simulated training guidance, and the utilization rate of training rooms is very low.

\subsection{The Students' Foundation Is Relatively Poor and Their Enthusiasm for English Learning Is Lacking.}

Due to the influence of examination methods and admission batches, compared with ordinary colleges and universities, students in higher vocational colleges have a relatively poor knowledge base and a generally low interest in English learning. Business English is a branch of English major, so students naturally reject it, consciously or subconsciously. In addition, the old teaching methods of teachers, the lack of training facilities and opportunities, make students' interest wear and tear down, and finally they become indifferent, making the teaching effect more difficult to improve.

\section{BUSINESS ENGLISH TEACHING REFORM FROM THE PERSPECTIVE OF "INSTRUMENTALITY"}

Business English is essentially a kind of English for special purpose, so the teaching of business English itself belongs to the category of "ESP" teaching, which is discussed intensively at present. Combined with the practical and application-oriented requirements of higher vocational colleges, it is of great significance and value to highlight the "instrumentality" in Business English Teaching in higher vocational colleges, which can be explored from the following aspects.

\subsection{Strengthen Teachers' Professional Cognition, Highlight the Professional Characteristics and Subject Orientation of Business English}

Teachers are the leading role in teaching, and students' cognition depends on Teachers' guidance to a great extent. Therefore, in order to strengthen the teaching effect, teachers' own quality and cognition are very important. Higher vocational colleges need to take effective ways to strengthen the teachers' cognition of the characteristics of business English specialty, and present the subject distinction between "business English" and "English" to the teachers simply and clearly, so that they can have a clear cognition and accurate positioning of the specialty. Therefore, it is possible to make students understand the major and its attributes through teachers, so as to change passive acceptance into active learning.

\subsection{Strengthen the Professional Quality of Teachers and Improve Their Practical Teaching Ability}

In view of the fact that most business English teachers have relatively strong language skills, but the business-related comprehensive quality and practical ability are generally poor, higher vocational colleges urgently need to take effective measures to strengthen the teachers' core professional quality and skills. Most of the graduates of "English education" in general colleges and universities are not qualified for business English teaching without special training or practical business work experience. Higher vocational colleges need to strengthen the quality of teachers from the source. At the same time, they should broaden the recruitment channels, seek talents with practical experience, and enrich the team of dual teachers. For current teachers, various forms of training can be provided. If necessary, they can be dispatched to the cooperative enterprises to carry out fixed post training to improve their practical guidance ability. In a word, try all possible methods to improve the overall quality of teachers to meet the needs of professional teaching.

\subsection{Strengthen the Construction of Practice and Training Sites Inside and Outside the School, and Provide Necessary Support for Teaching Reform}

Strictly implement the relevant national professional teaching standard documents, strengthen the construction 
of practice and training site, and equip with perfect practice and training equipment to support the professional teaching reform. As a cross-cultural subject, business English language skills need to be closely combined with business scenes to achieve practical training effect. Perfect practice and training sites can provide teachers with necessary places and means for project-based teaching and situational teaching. While training students' practical ability, they can help teachers to get rid of the traditional teaching method based on lectures to a large extent, and present the language knowledge into the real practice cases, so that students can master the key points in the whole process of participation and improve their interests in learning.

\subsection{Strengthen Students' Professional Cognition, and Publicly Emphasize the Tool Attribute of Business English Major}

At the beginning of students' enrollment, begin to carry out professional cognitive training to them, publicizing and emphasizing that the ultimate training purpose of business English is not to let students take exams, but to let them learn to use English to achieve the expected goal. With continuous preaching, change students' habitual cognition, help them to understand their major correctly, so as to consciously adjust the focus of their learning and training, and strive to change the learning state of passive acceptance into the state of active exploration and conscious training

\subsection{Optimize the Teaching Evaluation System, Guide Teachers and Students to Transfer the Teaching Focus to Practical Ability}

Colleges should appropriately reduce the proportion of all kinds of tests that focus on vocabulary, syntax and other language knowledge in teaching evaluation, gradually increase the results oriented assessment factors based on projects, and guide teachers and students to shift their focus to the effective use of language tools to complete simulation tasks. For example, they can try to design project examinations. Devide students into groups. Each group chooses its own topic within the specified range, sets the scene according to the regulations, and presents it in the form of simulation business project. Finally, according to the presentation and the realization of the project task, the teaching and learning effect can be evaluated objectively.

\section{SUMMARY}

In a word, the development history of business English in China is relatively short, but the market demand for business English professionals is still growing. As the training base of technical talents, higher vocational colleges still face many problems and difficulties in the exploration of business English teaching reform. Only by remembering the tool attribute of this major can we always adhere to the right direction and initial mission in the long process of teaching reform.

\section{REFERENCES}

[1] Zhang Jiarui, Su Qian, Yang Siqi. Review of business English research at home and abroad (2011-2017) [J]. Business foreign language research, 2019 (01): 7-22

[2] Shen Qi. From tools to resources: a new paradigm of College English Teaching Reform [n]. China Science Daily, July 31, 2019 (004)

[3] Li Li, Hou Xiaowei. A review of business English research papers in recent ten years in China (2007-2016) [J]. Journal of Hubei correspondence university, 2017,30 (08): $148-149+194$

[4] Liu Zeqing, Liu Yongliang. The realistic context and practical path of College English instrumentality and Humanity -- Based on the interview of College English teachers [J]. Journal of Inner Mongolia Normal University (EDUCATION SCIENCE EDITION), 2019,32 (10): 114-118

[5] Chen Pu. Research on business English Teaching of Applied Undergraduate Course [J]. Education and teaching forum, 2019 (48): 128-129

[6] Ge Jingping. The unity of instrumentality and Humanity -- on the new requirements of College English Teaching in the era of ESP [J]. Education and teaching forum, 2019 (05): 87-88

[7] Ling Xiaoqing. Reflections on the integration of College English teaching tools and humanity [J].

Overseas English, 2018 (23): 86-88

[8] Wang Lingli. College English teaching reform from the perspective of instrumental rationality and value rationality $[\mathrm{J}]$. Journal of Guiyang University (SOCIAL SCIENCES EDITION), 2019,14 (05): 119-121 